\title{
Black Theology and Pedagogy
}




\section{Black Religion/Womanist Thought/Social Justice Series Editors Dwight N. Hopkins and Linda E. Thomas Published by Palgrave Macmillan}

"How Long this Road": Race, Religion, and the Legacy of C. Eric Lincoln Edited by Alton B. Pollard, III, and Love Henry Whelchel, Jr.

African American Humanist Principles: Living and Thinking Like the Children of Nimrod

By Anthony B. Pinn

White Theology: Outing Supremacy in Modernity

By James W. Perkinson

The Myth of Ham in Nineteenth-Century American Christianity: Race, Heathens, and the People of God

By Sylvester Johnson

Loving the Body: Black Religious Studies and the Erotic

Edited by Anthony B. Pinn and Dwight N. Hopkins

Transformative Pastoral Leadership in the Black Church

By Jeffery L. Tribble, Sr.

Shamanism, Racism, and Hip Hop Culture: Essays on White Supremacy and Black Subversion

By James W. Perkinson

Women, Ethics, and Inequality in U.S. Healthcare: "To Count Among the Living" By Aana Marie Vigen

Black Theology in Transatlantic Dialogue: Inside Looking Out, Outside Looking In By Anthony G. Reddie

Womanist Ethics and the Cultural Production of Evil

By Emilie M. Townes

Whiteness and Morality: Pursuing Racial Justice through Reparations and

Sovereignty

By Jennifer Harvey

Black Theology and Pedagogy

By Noel Leo Erskine

The Theology of Martin Luther King, Jr. and Desmond Mpilo Tutu

By Johnny B. Hill

(forthcoming)

Conceptions of God, Freedom, and Ethics in African American and Jewish Theology By Kurt Buhring

(forthcoming) 


\title{
Black Theology and Pedagogy
}

\author{
Noel Leo Erskine
}




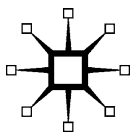

BLACK THEOLOGY AND PEDAGOGY

Copyright @ Noel Leo Erskine, 2008.

Softcover reprint of the hardcover 1st edition 2008 978-1-4039-7740-3

All rights reserved.

First published in 2008 by

PALGRAVE MACMILLAN ${ }^{\circledR}$

in the US-a division of St. Martin's Press LLC,

175 Fifth Avenue, New York, NY 10010.

Where this book is distributed in the UK, Europe and the rest of the world, this is by Palgrave Macmillan, a division of Macmillan Publishers Limited, registered in England, company number 785998, of Houndmills, Basingstoke, Hampshire RG21 6XS.

Palgrave Macmillan is the global academic imprint of the above companies and has companies and representatives throughout the world.

Palgrave ${ }^{\circledR}$ and Macmillan ${ }^{\circledR}$ are registered trademarks in the United States, the United Kingdom, Europe and other countries.

ISBN 978-1-349-73810-6

ISBN 978-0-230-61377-5 (eBook)

DOI 10.1057/9780230613775

Library of Congress Cataloging-in-Publication Data is available from the Library of Congress.

A catalogue record for this book is available from the British Library.

Design by Newgen Imaging Systems (P) Ltd., Chennai, India.

First edition: August 2008

109876654321

Transferred to Digital Printing in 2011. 
In memory of my father The Rev. U.N. Leo Erskine My first mentor of pedagogy and theology 



\section{Contents}

Preface

Introduction 1

1. Pedagogy and Black Community 17

2. What Can a Black Woman Teach Me? 45

3. Pedagogy and Ontological Sameness 69

4. The Black Church and Pedagogy 93

5. Emancipatory Praxis and Liberation for Oppressors 117

$\begin{array}{ll}\text { 6. Pedagogy as Celebration } & 143\end{array}$

$\begin{array}{ll}\text { Notes } & 161\end{array}$

$\begin{array}{ll}\text { Bibliography } & 169\end{array}$

$\begin{array}{ll}\text { Index } & 173\end{array}$ 



\section{Preface}

This book had its genesis in a three-year consultation on Pedagogy and Theology at the Wabash Center for Teaching and Learning during summers 1996-1999. There were about a dozen of us theologians who met under the leadership of Bill Placher, who pressed us to tease out the implications of our construction of theology as source and resource for excellence in teaching and learning. One of the advantages of this consultation was each of us had the opportunity to present a perspective on theology and pedagogy and receive critical comments from members of the consultation. I would like to pay special tribute to Serene Jones and Miroslav Volf with whom I discussed many of the central ideas for this project, especially in its early stages.

I am also grateful for a research luncheon with "The Dark Tower," a group of faculty and administrators from the Institute of the Liberal Arts at Emory University, who engaged me in critical dialogue around the salient ideas offered in this text. My colleagues in the Graduate Division of Religion at Emory were also instructive in the fall conversation in which I shared the central ideas of this book. Expressions of thanks are due to Wendy Farley, Mark Jordan, Ian McFarlane, Walt Lowe, and Joy McDougal.

To the editors of this series Linda Thomas and Dwight Hopkins I am indebted for much feedback from the original draft of the manuscript. Others who helped me think through several of the ideas presented in this text are: Mary Elizabeth Moore, Theodore Brelsford, and Anthony Pinn. John Snarey with whom I have had several discussions about this project contributed greatly.

Anthony Reddie at the Queens Foundation for Ecumenical Theological Education, Birmingham, United Kingdom has been an invaluable colleague in helping me work through the connections between pedagogy and its ecclesial context.

A special word of gratitude to my students, both in systematic theology and cross-cultural theologies, for many insights gleaned from 
class presentations. Many thanks to Estelle Archibold who helped with the bibliography and Alvelyn Sanders who assisted with editing.

The central question this book engages is: what are the implications for pedagogy in the classroom and in ecclesial settings if texts and contexts that have been excluded become essential for teaching and learning.? Because I write and reflect on this question from my social location in the African Diaspora, the reader will note that I make the case for the inclusion of the Black community in contexts of teaching and learning. The scriptures enjoin us to "honor our parents" and from a Black perspective this means our ancestors, our "sheroes," and heroes, our mothers, sisters, and of course our brothers and fathers. To refine and rephrase the question with which this book is concerned, I ask: What would it look like to "teach in Black?" that is not only to use token texts by Black authors but to allow these texts in the context of Black culture and history to shape the questions that are generative.

For many of my colleagues the attempt to teach in Black is comparable to struggle with the cross of Blackness. The immediate reaction to the cross is flight. The cross frightens and repulses us and raises the question of what would "discipleship to the cross" (the Black experience) entail as a pedagogical strategy? This question is important not only for White people who struggle with appropriate texts to use and how to engage Black issues in class, but also for Black scholars who seek to demonstrate their proficiency in Euro-American culture and thereby marginalize Black history and culture.

The good news for both White and Black persons who engage the cross of Blackness is the discovery that the cross heals and transforms. Black is beautiful.

It is my hope that this book identifies and isolates several of the unique contributions that Black and womanist theologies bring to excellence in teaching and learning. In many ways I am beginning a conversation that I hope others will join.

Noel Leo Erskine Emory University 